\title{
PENGARUH OUTPUT PERTANIAN DAN PARIWISATA TERHADAP PERTUMBUHAN EKONOMI DI INDONESIA
}

\author{
Haryani $^{\left.1^{*}\right)}$ dan Asrida ${ }^{\left.2^{*}\right)}$ \\ ${ }^{1,2)}$ Fakultas Ekonomi, Universitas Almuslim \\ *) E-mail: haryani_68@yahoo.co.id dan asrida03@gmail.com
}

\begin{abstract}
Penelitian ini bertujuan untuk menjelaskan pengaruh output pertanian dan pariwisata terhadap pertumbuhan
ekonomi Indonesia. Untuk mendapatkan hasil yang maksimal, maka data yang digunakan data sekunder
yang bersifat time series yaitu data pertumbuhan ekonomi, output pertanian dan untuk data pariwisata
digunakan data jumlah kedatangan turis mancanegara di Indonesia selama 24 tahun terakhir yaitu tahun
1995-2019 yang bersumber dari World Bank dengan teknik analisis regressi linear berganda. Hasil penelitian
menunjukkan bahwa Output pertanian dan pariwisata berpengaruh positif terhadap pertumbuhan ekonomi di
Indonesia.
Kata Kunci : Output Pertanian, Pariwisata dan Pertumbuhan Ekonomi
\end{abstract}
\section{Pendahuluan}

Pertumbuhan ekonomi merupakan proses perubahan kondisi perekonomian suatu negara secara berkesinambungan menuju keadaan yang lebih baik selama periode tertentu. Pertumbuhan ekonomi bisa dilihat dari sejauh mana barang dan jasa yang diproduksi masyarakat dapat meningkat dan mereka memperoleh kesejahteraan dari memproduksi barang dan jasa tersebut. Tujuan dari pertumbuhan ekonomi adalah mencapai tingkat kemakmuran yang lebih tinggi. Dalam mencapai tujuan tersebut pemerintah harus ikut campur tangan secara aktif untuk mempengaruhi gerak perekonomian.

Sektor pertanian merupakan sektor utama yang memberikan kontribusi cukup besar dalam pembangunan ekonomi Indonesia. Sektor pertanian berperan penting dalam pembangunan ekonomi nasional yaitu berperan secara langsung dalam menyediakan kebutuhan pangan masyarakat, berperan dalam pembentukan pendapatan Produk Domestik Bruto (PDB), menyerap tenaga kerja dipedesaan, berperan dalam penghasilan devisa dan atau penghematan devisa, dan berperan dalam pengendalian inflasi. Dengan demikian sektor pertanian secara tidak langsung berperan dalam menciptakan iklim yang konsuntif bagi pembangunan sektor ekonomi lainnya.

Adanya peran sektor pertanian yang diberikan untuk pembangunan ekonomi di
Indonesia, membuat sektor pertanian harus terus dikembangkan oleh pemerintah, namun di sisi lain peran sektor pertanian pun telah terjadi fluktuatif dan cenderung turun, penyebab utama terjadinya penurunan peran sektor pertanian adalah pertumbuhan produksi pertanian yang masih terlalu berbasis pada ketersediaan lahan, padahal ada beberapa kegiatan ekonomi yang disertai konversi lahan pertanian yang menjadi kegunaan lain masih terus berlangsung. Tidak hanya itu saja, kondisi sektor pertanian sekarang pun sedang mengalami gejala penerimaan output yang terus berkurang dikarenakan alokasi dan kombinasi dari faktor produksi pertanian yang digunakan masih dikatakan belum mampu untuk mengimbangi penurunan yang sedang terjadi.

Disamping sektor pertanian, sektor pariwisata juga memainkan peran penting dalam pembangunan ekonomi Indonesia, yaitu kontribusinya dalam penerimaan, penyerapan tenaga kerja. Kedatangan wisatawan ke suatu daerah akan membuka peluang bagi masyarakat lokal untuk bekerja sehingga masyarakat akan memperoleh pendapatan dari pekerjaan tersebut. Sektor pariwisata secara langsung dapat menciptakan permintaan baik segi konsumsi maupun investasi yang akan menimbulkan kegiatan produksi barang dan jasa. Penelitian ini bertujuan untuk menjelaskan pengaruh Output Pertanian dan Jumlah Kunjungan Wisatawan terhadap Pertumbuhan Ekonomi di Indonesia. 


\section{Kajian Teoritis}

\section{Pertumbuhan Ekonomi}

Menurut Arsyad

(2015:111)

pertumbuhan ekonomi diartikan sebagai kenaikan Produk Domestik Bruto atau Pendapatan Nasional Bruto tanpa memandang apakah kenaikan tersebut lebih besar atau lebih kecil dari tingkat pertumbuhan penduduk atau apakah perubahan struktur ekonomi terjadi atau tidak.

Sukirno (2016:185) mengartikan pertumbuhan ekonomi sebagai perkembangan kegiatan dalam perekonomian yang menyebabkan barang dan jasa yang diproduksi meningkat dalam kegiatan ekonomi masyarakat, pertumbuhan menyangkut perkembangan yang berdimensi tunggal dan diukur dengan meningkatnya hasil produksi dan pendapatan.

Prof. Simon Kuznets mendefinisikan pertumbuhan ekonomi sebagai kenaikan jangka panjang dalam kemampuan suatu negara untuk menyediakan semakin banyak jenis barang-barang ekonomi kepada penduduknya, kemampuan ini tumbuh sesuai dengan kemajuan teknologinya dan penyesuaian kelembagaan dan ideologis negara yang bersangkutan (Jhingan, 2016:22).

Pertumbuhan ekonomi adalah proses kenaikan output perkapita dalam jangka panjang. Tekanannya pada tiga aspek, yaitu: proses, output perkapita dan jangka panjang. Pertumbuhan ekonomi adalah suatu proses,bukan suatu gambaran ekonomi pada suatu saat. Disini kita melihat aspek dinamis dari suatu perekonomian, yaitu bagaimana suatu perekonomian berkembang. Tekanannya ada pada perubahan atau perkembangan itu sendiri (Boediono, 2015:1).

\section{Output Pertanian}

Output pertanian merupakan kontribusi sektor pertanian di dalam GDP yang dilihat dari laju pertumbuhan GDP sektor pertanian, yang dihitung berdasarkan pendekatan produksi. Satuan dari variabel output pertanian adalah persen (BPS, 2019). Output pertanian diperoleh dalam GDP dengan menggunakan pendekatan produksi yang dilakukan oleh Badan Pusat Statistik. Output pertanian berperan di dalam perekonomian nasional melalui pembentukan laju pertumbuhan Gross Domestic Product (GDP),

Output pertanian diperoleh langsung dari sektor pertanian sebagai bentuk penyediaan pangan dan bahan baku industri, pengentasan kemiskinan, penyedia lapangan kerja dan peningkatan pendapatan masyarakat. Selain kontribusi langsung, output pertanian dari sektor pertanian juga memiliki kontribusi yang tidak langsung berupa efek pengganda (multiplier effect), yaitu keterkaitan input-output antar industri, konsumsi dan investasi. Dampak pengganda tersebut relatif besar sehingga sektor pertanian layak dijadikan sebagai sektor andalan dalam pembangunan ekonomi nasional.

\section{Pariwisata}

Istilah pariwisata baru mancul di masyarakat di masyarakatkira-kira pada abad ke-18, khususnya sesudah Revolusi Industri di Inggris. Istilah pariwisata berasal dari dilaksanakannya kegiatan wisata (tour), yaitu suatu aktivitas perubahan tempat tinggal sementara dari seseorang, di luar tempat tinggal sehari-hari dengan suatu alasan apa pun selain melakukan kegiatan yang bisa menghasilkan upah atau gaji (Muljadi, 2017:199). Sedangkan menurut Kodhyat dalam Kurniansah (2016:9) pariwisata adalah perjalanan dari satu tempat ketempat lain bersifat sementara, dilakukan perorangan atau kelompok, sebagai usaha mencari keseimbangan atau keserasian dan kebahagiaan dengan lingkungan dalam dimensi sosial budaya, alam, dan ilmu.

Defenisi yang luas pariwisata adalah perjalanan dari suatu tempat ke tempat lain, bersifat sementara, dilakukan perorangan maupun kelompok, sebagai usaha mencari keseimbangan atau keserasian dan kebahagiaan dengan lingkungan hidup dalam dimensi sosial, budaya,alam dan ilmu. Suatu perjalanan akan dianggap sebagai perjalanan wisata bila memenuhi tiga persyaratan yang diperlukan, yaitu bersifat sementara, bersifat sukarela (Voluntary) dalam arti tidak terjadi karena paksaan, dan tidak bekerja yang sifatnya menghasilkan upah.

\section{Metodelogi}

Jenis penelitian yang digunakan adalah penelitian kuantitatif dan data sekunder yang bersifat time series yaitu data pertumbuhan ekonomi, output pertanian dan untuk data pariwisata digunakan data jumlah kedatangan turis mancanegara di Indonesia selama 24 tahun terakhir yaitu tahun 1995-2019 yang bersumber dari World Bank.

Teknik analisis data yang digunakan adalah analisis linear berganda. Analisis linear berganda digunakan untuk menguji ada tidaknya pengaruh output pertanian dan jumlah kedatangan turis mancanegara terhadap 
pertumbuhan ekonomi di Indonesia dengan persamaan sebagai berikut (Gujarati, 2016) :

Dimana:

$$
Y=a+b_{1} X_{1}+b_{2} X_{2}+e
$$

$Y \quad$ : Pertumbuhan Ekonomi

$\mathrm{X}_{1}$ : Output Pertanian

$\mathrm{X}_{2}$ : Jumlah kedatangan turis mancanegara

a : Konstanta/ Intercept

b : KoefisienRegresi

e : Standar Error

\section{Hasil dan Pembahasan Analisis Regresi}

Analisis regresi linear berganda dalam penelitian ini digunakan untuk mengetahui pengaruh dari variable output pertanian (X1) dan pariwisata $(X 2)$ terhadap variabel terikat pertumbuhan ekonomi $(Y)$ di Indonesia baik secara simultan maupun secara parsial

Tabel 1. Analisis Of Variance (ANOVA) pertanian dengan pertumbuhan ekonomi di Indonesia.

3. Koefisien regresi pariwisata(X2) sebesar 0,254 artinya setiap terjadi peningkatan pada variabel pariwisata sebesar 1 persen, maka akan meningkatkan pertumbuhan ekonomi(Y) di Indonesia sebesar 0,254\%. Hal ini menunjukkan adanya hubungan negative atau searah antara variabel pariwisata dengan pertumbuhan ekonomi di Indonesia.

4. Berdasarkan pengujian dengan menggunakan software SPSS 18.0, maka diperoleh nilai koefisien korelasi (R) sebesar 0,617 atau $61,7 \%$. Menurut Sugiyono (2014:183) menyatakan bahwa tingkat hubungan 0,60-0,799 memiliki hubungan yang kuat. Dengan demikian dapat disimpulkan bahwa output pertanian dan pariwisata memiliki hubungan yang kuat dengan pertumbuhan ekonomi di Indonesia.

Tabel 1. Analisis Of Variance (ANOVA)

\begin{tabular}{|c|c|c|c|c|c|}
\hline \multirow[b]{2}{*}{ Nama Variabel } & \multicolumn{3}{|c|}{ Standar } & \multirow[b]{2}{*}{$t_{\text {tabel }}$} & \multirow[b]{2}{*}{ Sig. } \\
\hline & B & Error & $t_{\text {hitung }}$ & & \\
\hline Konstanta & $-3,987$ & 2,566 & $-1,553$ & 2,042 & 0,094 \\
\hline Output Pertanian & 1,498 & 0,377 & 3,974 & 2,042 & 0,000 \\
\hline Pariwisata & 0,254 & 0,111 & 2,277 & 2,042 & 0,031 \\
\hline Koefisien korelasi $(R)=0,617$ & & a. Variabel & prediktor: & output & pertanian \\
\hline $\begin{array}{l}\text { Koefisien determinasi }\left(R^{2}\right)=0,380 \\
F_{\text {ittung }}=8,584\end{array}$ & & dan pariv & & & mbuhan \\
\hline $\begin{array}{l}\mathrm{F}_{\text {hitung }}=0,004 \\
\mathrm{~F}_{\text {tabel }}=2,92 \\
\text { Sig } F=0,001\end{array}$ & & Ekonomi & & & intouran \\
\hline
\end{tabular}

Sumber: Data Sekunder, 2020 (diolah).

Berdasarkan hasil uji statistik regresi linear berganda, maka diperoleh persamaan sebagai berikut:

$$
Y=-3,987+1,498 X_{1}+0,254 X_{2}+e
$$

Dari persamaan tersebut di atas dapat dijelaskan beberapa hal, sebagai berikut:

1. Nilai konstanta (a) yaitu $-3,987$ ini berarti bahwa apabila variabel bebas (output pertanian dan pariwisata) sama dengan nol (0), maka pertumbuhan ekonomi di Indonesia adalah sebesar-3,987\%.

2. Koefisien regresi output pertanian(X1) sebesar 1,498 artinya setiap terjadi peningkatan pada variable output pertanian(X1) sebesar 1 persen, maka akan meningkatkan pertumbuhan ekonomi(Y) di Indonesia sebesar 1,498\%, dengan asumsi seluruh variabel-variabel bebas lainnya konstan. Hal ini menunjukkan adanya hubungan negative atau searah antara variabel output
Nilai koefisien determinasi $\left(R^{2}\right)$ sebesar 0,380 yang menandakan bahwa sebesar $38,0 \%$ pertumbuhan ekonomi di Indonesia, dijelaskan oleh variabel-variabel independen; output pertanian dan pariwisata, sedangkan sisanya sebesar $62,0 \%$ dipengaruhi oleh faktorfaktor lain yang tidak teramati dalam penelitian ini.

Berdasarkan hasil di atas dapat dibuktikan bahwa Pertumbuhan ekonomi di Indonesia sangat dipengaruhi oleh variabelvariabel bebas yaitu output pertanian(X1) dan pariwisata (X2). Variabel-variabel tersebut secara bersama-sama mempunyai pengaruh positif dan signifikan terhadap Pertumbuhan ekonomi di Indonesiayaitu dengan nilai $F_{\text {hitung }}$ sebesar 8,584 dan $F_{\text {tabel }}$ sebesar 2,92 dengan tingkat signifikansi 0,001 . Dengan demikian dapat disimpulkan bahwa secara simultan variabel-variabel bebas yang diteliti berpengaruh positif terhadap pertumbuhan ekonomi di Indonesia. 


\section{Pengujian Secara Parsial}

Adapun statistik uji t digunakan untuk mengetahui pengaruh masing-masing variabelvariabel independen; output pertanian(X1) dan pariwisata (X2) terhadap pertumbuhan ekonomi di Indonesia. Dari hasil pengujian statistik diperoleh nilai $t_{\text {hitung }}$ sebesar 3,974 untuk variabel output pertanian(X1) dan sebesar 2,277 untuk variabel pariwisata(X2). Adapun nilai $t_{\text {tabel }}$ untuk ukuran sampel 24 data pada tingkat signifikansi $(\alpha)=5 \%$ adalah 2,042 . Dengan membandingkan nilai $t_{\text {hitung }}$ dan nilai $t_{\text {tabel }}$ maka diperoleh kesimpulan bahwa secara parsial variabel output pertanian dan pariwisata berpengaruh positif dan signifikan terhadap pertumbuhan ekonomi di Indonesia.

$$
\text { Keberhasilan pembangunan di }
$$

Indonesia di samping ditentukan oleh besarnya output pertanian juga dipengaruhi oleh besarnya tingkat kedatangan turis. Kedatangan turis manca negara ke Indonesia sangat memiliki peran penting dalam perekonomian, karena berkontribusi terhadap pendapatan daerah, berpotensi meningkatkan kesejahteraan masyarakat di sekitar lokasi obyek wisata yang bersangkutan. Kedatangan turis manca negara memiliki multiplier effect yang dapat memacu timbulnya kegiatan lain dengan menggerakkan industri-industri lain untuk meningkatkan devisa, dan mampu menampung kesempatan kerja dan kesejahteraan masyarakat.

Berdasarkan hasil pengolahan data variabel output pertanian dan pariwisata berpengaruh positif dan signifikan terhadap pertumbuhan ekonomi di Indonesia. Hasil penelitian ini sejalan dengan pendapat Asaleye, et., al. (2018:791) dalam penelitiannya menemukan bahwa ada hubungan signifikan antara output pertanian dengan pertumbuhan ekonomi baik secara jangka panjang maupun jangka pendek. Diperkirakan rata-rata 1\% peningkatan nilai output pertanian akan menyebabkan sedikit peningkatan GDP riil. Sedangkan menurut Jalil, at; al., (2013:1) menunjukkan bahwa jumlah wisatawan mancanegara atau wisatawan internasional berpengaruh positif pada pertumbuhan ekonomi di Pakistan.

\section{Kesimpulan}

Berdasarkan hasil penelitian di atas, maka dapat disimpulkan bahwa Output pertanian dan pariwisata berpengaruh positif terhadap pertumbuhan ekonomi di Indonesia.

\section{Daftar Pustaka}

Arikunto. Suharsimi. (2008). Metodologi Penelitian. Jakarta. Rineka Cipta.

Arsyad, Lincolin. 2015.2 Ekonomi Pembangunan, UPP STIM YKPN: Yogyakarta.

Asaleye, A. J., Fashina, O. A., Ogunjobi, J. O. and Lawal, A. I. 2018. Foreign aid, human capital and economic growth nexus: Evidence from Nigeria. Accepted for publication in Journal of International Studies 11(2) (www.jois.eu).

Boediono. 2015. Ekonomi Internasional dan Pengantar IImu Ekonomi. Penerbit : BPFE UGM.

BPS Indonesia. 2018. ProdukDomestiBruto $(P D B)$. Jakarta.

Jhingan, M. L. 2016. Ekonomi Pembangunan danPerencanaan.PT.

Raja GrafindoPersada: Jakarta.

Sukirno,

Sadono. 2016. MakroekonomiTeoriPen gantar. PT. Raja GrafindoPersada: Jakarta.

Todaro, Michael P. and Smith, Stephen C. 2016. Economic Development.Eleventh Edition. United States: Addison Wesley.

Todaro, M.P. 2014. Economic Development.Seventh Edition. Addition Wesley Longman, Inc: New York.

World Bank. 2019. The World Bank Annual Report 2019. https: // data. worldbank. org. 